\title{
PERSEPSI MASYARAKAT TERHADAP PENYIARAN DAKWAH ISLAMIYAH MELALUI TELEVISI SWASTA DI KOTA BANJARMASIN
}

\author{
Supriyadi Hadi Saputra
}

UIN Antasari Banjarmasin

\begin{abstract}
This research is a field research which is sampling study. The sample is taken from by using porpusive sampling technique as many as 50 people with sample distribution as many as 10 people from 5 districts in Banjarmasin. Data collection technique is done by conducting interviews to the respondents, which then analysis is done qualitatively.

From the results of the study note that from 50 respondents who are the authors carefully, then their perceptions can be categorized in two groups of opinions. The first group consists of 38 respondents who argue that broadcasting Islamic da'wah through private television in the city of Banjarmasin is a new pattern in Islamic da'wah. Because most da'wah in the past done only by using simple media, ie through direct meeting or assembly taklim. So someone who wants to follow an Islamic da'wah activities should come to the place of da'wah. This second group consists of 12 respondents who argue that broadcasting Islamic da'wah through private television in Banjarmasin City is a new pattern in da'wah Islamiyah, in the local context. But not enough, and need to be upgraded in the packaging or form of lecture, which is more compressed on the interactive form. The reason of the first group that the da'wah through media tekevisi broadcast by private television in the city of Banjarmasin, shows dakwah in Banjarmasin is a significant increase.

According to this first group, private television programs broadcasting propagation programs such as TV Ambassador and Banjar TV are good enough, because the material of dakwah is quite varied, such as ketauhidan, Islamic law, and morals. Then there is also a commentary of the hadith of the Prophet Muhammad SAW. but according to this second group, the da'wah broadcast by private television in Banjarmasin city is good enough, but still need to be improved again its dakwah program. Like more interactive dialogue compared to da'wah in the form of non-interactive religious lectures.
\end{abstract}

Keywords: television, broadcasting, da'wah 


\section{Pendahuluan}

Kemajuan dan perkembangan Islam tidak akan terjadi tanpa adanya dakwah. Salah satu perintah agama Islam adalah melakukan aktivitas dakwah jika ingin agama itu bisa dikenal, dipahami dan diamalkan ajaran-ajarannya.

Dalam menyampaikan dakwahnya, seorang dai dapat menggunakan salah satu metode, yang sekiranya sesuai dengan keahliannya dan juga sesuai sesuai pula dengan kondisi mad'u, agar dakwahnya mencapai tujuan. Dakwah dapat dilakukan dengan dakwah bil-lisan, dakwah bil-kitab, yaitu dakwah dengan menggunakan keterampilan tulis-menulis, dakwah bil-hal, yaitu dakwah yang dilakukan melalui berbagai kegiatan yang langsung menyentuh kepada masyarakat dan dakwah sengan memanfaatkan alat elektronik seperti radio, televisi, dan lain-lain.

Selain beberapa hal tersebut di atas, para ulama dan juru dakwah Indonesia, bahkan di Kota Banjarmasin juga menggunakan media elektronik, seperti televisi dalam penyiaran dakwah. Tercatat ada tiga buah televisi lokal swasta di Kota Banjarmasin yang menyiarkan acara dakwah Islamiyah, baik berupa ceramah agama, pengajian majelis taklim, dan dialog keagamaaan secara interaktif. Televisi- televisi swasta itu adalah Duta Tv, Banjar Tv, dan TVB.

Melihat maraknya acara dakwah di televisi-televisi swasta itu menimbulkan persepsi yang kontradiktif di kalangan masyarakat Islam di Kota Banjarmasin, ada yang memandang keberadaaan program dakwah itu sangat baik dalam konteks penyiaran dakwah secara elektronik dan modern bagi umat Islam yang tidak sempat menghadiri majelis taklim atau pengajian agama, dan ada pula yang berpandangan bahwa program program dakwah itu biasabiasa saja, karena di Kota Banjarmasin sudah banyak pengajian-pengajian agama dan majelis taklim yang dapat diikuti secara langsung, bahkan terprogram dengan baik. Yang cukup ekstrim adalah adanya pandangan sebagian masyarakat, bahwa program itu hanya untuk menarik pemirsa agar membuka program TV tertentu supaya rating TV tersebut makin tinggi dan mendapatkan keuntungan yang besar.

Yang menjadi permasalahan adalah, apakah keberadaan dakwah Islamiyah melalui pesawat televisi swasta baik Duta TV, Banjar TV, maupun TVB itu mendapat tanggapan yang positif bagi masyarakat muslim di Kota banjarmasin? Ataukah justru kurang mendapatkan tanggapan yang positif. Pernyataan ituu timbul, akibat banyaknya 
media televisi swasta dan nasional yang menyiarkan acara-acara yang tidak benuansa Islami, tetapi dikemas sangat menarik, sehinnga dapat mengalihkan perhatian masyarakat muslim Kota Banjarmasin dari acara-acara yang bernuansa Islami di televisi swasta lokal.

\section{Pembahasan}

1. Pengertian Persepsi

$$
\begin{array}{lrr}
\begin{array}{r}
\text { Persepsi } \\
\text { adalah }
\end{array} & \begin{array}{r}
\text { tanggapan } \\
\text { (penerimaan) }
\end{array} \text { langsung } & \text { dari suatu } \\
\text { serapan. (Depdikbud, } & \text { 1989:759). }
\end{array}
$$
Persepsi bisa juga berarti daya penglihatan, daya tangkap penghilatan. (Hornby, dkk, 1984:235). Dalam kesempatan lain persepsi sebagai pengalaman tentang objek peristiwa atau hubungan-hubungan yang diperoleh dengan menyimpulkan informasi dan menafsirkan pesan-pesan. (Jalaluddin Rahmat, 1996:102).

Dengan demikian pengertian persepsi dapat dipahami sebagai suatu tanggapan atau pandangan seseorang terhadap suatu objek atau peristiwa yang ada dan diketahuinya.

2. Pengertian Masyarakat Islam

Masyarakat, seperti yang dikemukakan oleh Murthada Muthahhari dalam bukunya Society and History di definisikan sebagai berikut:

"suatu masyarakat terdiri dari kelompok - kelompok manusia yang saling terkait oleh sistem -sistem, adat istiadat, ritus - ritus serta hukum hukum khas, dan yang hidup bersama dalam satu wilayah tertentu. Sekawanan rusa hidup bersama, namun sekawanan rusa tersebut tidak bisa dikatakan sebagai masyarakat, karena mereka bukan manusia". (Murtadha Muthahhari, 1995:15).

Masyarakat Islam oleh syariat Islam diberi bermacam-macam patokan atau pedoman yang sangat penting, antara lain:

1) Pedoman (kaidah) akhlak dan perilaku

2) Pedoman sosial kemasyarakatan

3) Pedoman politik

4) Pedoman persaudaraan.

Masalah kemasyarakatan ini erat kaitannya dengan dakwah Islamiyah.

Persepsi masyarakat terhadap penyiaran dakwah Islamiyah melalui pesawat televisi cukup baik, karena masyarakat merasa terbantu karena mereka dapat menerima transmisi dakwah dirumah mereka. Terbukti rating televisi dakwah cukup baik. 
Penyiaran dakwah Islam merupakan suatu perbuatan yang diperintahkan oleh Allah swt dan juga Rasul-Nya. Ada beberapa firman Allah swt yang memerintahkan untuk berdakwah, diantaranya adalah sebagai berikut:

1. Firman Allah swt. dalam surah Ali-Imran ayat 104 yang artinya

"Dan hendaklah ada di antara kamu segolongan umat yang menyeru kepada kebajikan, menyuruh kepada yang ma'ruf dan mencegah dari yang munkar; merekalah orang-orang yang beruntung". (Departemen Agama RI, 1985:93).

Tidak sepatutnya bagi mukminin itu pergi semuanya (ke medan perang). Mengapa tidak pergi dari tiap-tiap golongan di antara mereka beberapa orang untuk memperdalam pengetahuan mereka tentang agama dan untuk memberi peringatan kepada kaumnya apabila mereka Telah kembali kepadanya, supaya mereka itu dapat menjaga dirinya. (Depag RI, 102-103).

Sementara dalam hadits tentang kewajiban berdakwah terdapat pada hadits berikut, sabda Rasulullah saw. antara lain:

1. Hadits Riwayat Bukhari
Artinya: "Dari Abdillah bin Amru bin Ash ra. Bahwasanya Rasulullah saw. bersabda: sampaikanlah dari ajaranku walaupun hanya satu ayat" (H.R Bukhari). (Abi Zakaria Yahya bin Syarif An-Nawawi, 1401 H:338).

\section{Hadits Riwayat Muslim}

Artinya: "Berkata Abu Said, saya mendengar Rasulullah saw. bersabda: Barang siapa di antara kamu melihat kemungkaran hendaklah mengubahnya dengan tangannya, jika tidak sanggup hendaklah dengan lisannya dan jika tidak sanggup hendaklah membencinya dalam hati, yang demikian itu adalah selemahselemahnya iman" (H.R Muslim). (Abi AlHusain Muslim bin Al-Hajjaj al-Qusyairi, $1401 \mathrm{H}: 46)$.

Arus globalisasi yang tidak terhindarkan mengakibatkan dunia terbentuk menjadi sebuah desa global (global village) yang ditandai dengan kemajuan teknologi informasi dan komunikasi. Hampir tidak ada batas jarak, ruang, dan waktu.

Hal ini mau tidak mau mempengaruhi corak keberagaman masyarakat (khususnya di perkotaan), karena itu metode dan media dakwah juga harus disesuaikan akibat kemajuan teknologi tersebut - meskipun metode 
dakwah secara tradisional tetap masih dipakai. Kini, penyampaian dakwah sudah tidak dibatasi pada khutbah, ceramah, pengajian, halakah, tabligh akbar, daurah dan sebagainya. Pesan-pesan dan nasihat agama bisa diakses melalui sms, internet, televisi, radio, rekaman $\mathrm{CD}$, dan bukubuku agama.

Cara keberagaman orang kota yang cenderung kemodernan-materialistik tersebut mempunyai ciri-ciri:

1. Terjadi sekularisasi dalam kehidupan beragama.

2. Pemahaman atau persepsi masyarakat yang telah mengalami pergeseran bahkan perubahan.

3. Nilai-nilai transenden dan moralitas banyak diremehkan orang.

4. Agama hanya sekedar sebagai alat instrumen kehidupan serta alat legitimasi dari apa yang diperbuat.

5. Dalam menghadapi problema kehidupan, agama memiliki peranan langsung sebagai alat memecahkan masalah, malah kadang tidak tampil sama sekali, ia dijadikan sebagai privat bisnis.

6. Otoritas agama semakin melemah, lembaga-lembaga keagamaan hanya diminati oleh sebagian kecil
7. Sektor-sektor umum yang dominan seperti industri, politik, dan hukum telah dilepaskan dari tujuan-tujuan agama yang mengikat.

Boleh dikatakan hampir tidak ada satu desapun dinegeri kita yang tidak terjangkau oleh aliran listrik. Listrik masuk desa sudah bukan semboyan lagi. Dengan demikian, selain masyarakat sudah tidak lagi menggunakan lampu minyak yang "meng" hidung mereka untuk alat penerang, mereka juga dapat menyaksikan tayangan-tayangan televisi baik dari stasiun televisi dalam negeri maupun luar.

Perkembangan media sebenarnya diikuti oleh tuntutan kepada media untuk memiliki suatu tanggungjawab sosial. Kebebasan yang dimiliki media perlu disertai tanggungjawab sosial dan kecenderungan berorientasi pada kepentingan umum, baik secara individual maupun kelompok.

Dakwah melalui televisi mempunyai dua segmen dasar yaitu penglihatan (visual) dan (audio), misalnya kata-kata, musik, atau suara lain. Proses penciptaannya biasa dimulai dengan gambar karena televisi lebih unggul didalam teknik gambarnya yang masyarakatnya. 
dapat bergerak. Disamping itu kata-kata dan suara juga harus diperhatikan.

Bentuk-bentuk iklan televisi sangat tergantung pada bentuk siarannya, apakah merupakan bagian dari suatu kongsi, jaringan, kabel atau bentuk lainnya.

Disamping memiliki kelebihankelebihan, media televisi pun juga memiliki-memiliki kelemahankelemahan sebagai media periklanan, kelebihan itu adalah sebagai berikut:

1. Kelebihan media televisi:

a. Mampu menjaga khalayak sasaran yang luas.

b. Mempunyai dampak yang sangat kuat terhadap yang sangat kuat terhadap konsumen, karena menekankan pada dua indera sekaligus, yaitu penglihatan dan pendengaran.

(Arif Sudaryana, 2009:24).

2. Kelemahan media televisi:

a. Biaya yang dikeluarkan besar, termasuk biaya untuk melakukan perubahan iklan.

b. Sulit melakukan segmentasi, karena khalayak yang dijangkau tidak selektif, sebab acara televisi disaksikan oleh semua lapisan masyarakat yang memiliki karakteristik yang berbeda-beda. (Arif Sudaryana, 2009:27)

Tentu saja kelebihan dan kelemahan televisi mempunyai pengaruh kepada pemirsanya. Semakin unsur kelebihan digunakan maka akan semakin besar pula kecenderungan untuk menikmatinya. Demikian sebaliknya bila unsur kelemahan yang lebih mendominasi maka hasilnya akan ditinggalkan khalayaknya.

Melihat perkembangan televisi yang demikian pesat, Wilbur Schramm mengatakan televisi telah digunakan secara efektif untuk mengajarkan segala macam subjek, baik teoritas maupun praktik. Maka tidak berlebihan bila Gerbner berkata bahwa media massa (khususnya media televisi) telah menjadi agama resmi masyarakat industri.

\section{Simpulan}

Ada tiga stasiun televisi swasta lokal yang ada di Kota Banjarmasin yang memprogramkan acara dakwah Islamiyah yaitu Duta TV, TVB (Banua), dan Banjar TV.

Dari 50 orang responden yang penulis teliti, maka persepsi mereka dapat 
dikategorikan dalam dua pendapat sebagaimana berikut ini:

1. Kelompok pertama

Kelompok pertama ini terdiri dari 38 orang responden yang berpendapat bahwa penyiaran dakwah Islamiyah melalui televisi swasta di Kota Banjarmasin merupakan suatu pola baru dalam dakwah Islamiyah.

Menurut kelompok pertama ini program acara televisi swasta yang menyiarkan siaran dakwah seperti Duta TV dan Banjar TV sudah cukup baik, karena materi dakwahnya cukup bervariasi, seperti masalah ketauhidan, hukum Islam, dan akhlak. Kemudian juga ada tafsir alquran dan hadist nabi muhammad saw.

Menurut kelompok pertama ini pembicara atau dai yang menjadi narasumber sudah merupakan para dai yang layak menyampaikan dakwah Islam. Seperti KH. Abdil Bahith di (Pengajian Agama/Majelis taklim) di Duta TV, Ustadz Drs. Sukarni, M. Ag, (Mutiara Kehidupan) di TV Banjar), KH. Umaini Hambali (pengajian agama) di TV B, dan beberapa dai lainnya.

Menurut kelompok pertama ini dari segi teknik penyampaiannya dakwah juga sudah sangat baik, yakni sesuai dengan kondisi masyarakat Kota Banjarmasin dengan dialog bahasa Indonesia, yang dicampur dengan Bahasa Arab dan Banjar. Sehingga mudah untuk dicerna atau diterima oleh pendengar siaran dakwah. Dakwah yang dilakukan melalui media televisi swasta di Kota Banjarmasin cukup bervariatif sehingga membuat para pendengar dakwah tidak jenuh mengikutinya.

2. Kelompok Kedua

Kelompok kedua ini terdiri dari 12 orang responden yang berpendapat bahwa penyiaran dakwah Islamiyah melalui televisi swasta di Kota Banjarmasin merupakan suatu pola baru dalam dakwah Islamiyah, dalam konteks lokal.

Menurut kelompok kedua ini, yang terdiri dari 12 orang responden, mereka berpresepsi bahwa keberadaan dakwah di televisi sudah ada sebelumnya, walaupun hal itu dilakukan oleh televisi pemerintah dan swasta nasional.

Menurut kelompok ini, dakwah yang disiarkan oleh televisi swasta yang ada di Kota Banjarmasin sudah cukup baik, tetapi masih harus diperbaiki lagi program acara dakwahnya. Seperti lebih banyak dialog interaktif dibandingkan 
dengan dakwah dalam bentuk ceramah agama non interaktif.

Berkenaan dengan materi dakwah, yaitu pesan yang akan disampaikan kepada mad'u atau pendengar televisi swasta di Kota Banjarmasin sudah tepat, yakni berkisar masalah keimanan, hukum Islam (fiqih, dan akhlak (tasawuf). Walaupun ada juga tartil alquran dan syair-syair maulid serta musik Islami.

Hal itu senada dengan pendapat Asmuni Syukir dapat dibagi dalam tiga pokok, yaitu:

a) Masalah Keimanan (Akidah).

b) Masalah Keislaman (Syariat).

c) Masalah budi pekerti (Akhlak).

(Asmuni Syukir, 1983:60).

Dengan demikian secara mendasar persepsi kedua kelompok masyarakat Kota Banjarmasin terhadap penyiaran dakwah Islamiyah melalui televisi swasta di Kota Banjarmasin berbeda satu sama lain, tetapi dapat dikompromikan.

\section{Daftar Pustaka}

Abi Al-Husain Muslim bin Al-Hajjaj AlQusyairi, Shahih Muslim, Beirut, Dar alFikr, $1401 \mathrm{H}$.
Abi Zakariya Yahya bin Syarif An-Nawawi, Riadhus Shalihin, Beirut, Dar al-Fikr, $1401 \mathrm{H}$.

Departemen Agama RI, Alquran dan Terjemahnya, Jakarta, Proyek Pengadaan Kitab Suci Al-Qur'an, 1989.

Depdikdub, Kamus Besar Bahasa Indonesia, Jakarta, Tim Penyusun Kamus Pusat Pembinaan dan Pengembangan Bahasa, 1989.

Effendi, Onong Uchjana, Televisi Siaran Teori dan Praktik, Bandung, CV. Remadja Karya, 1987.

Hornby, dkk, Kamus Inggris-Indonesia, Jakarta, Pustaka Ilmu, 1984.

Muriah, Siti, Metedologi Dakwah Kontemporer, Yogyakarta, Mitra Pustaka, 2000, cet-1.

Muthahhari, Murthada, Society and History, Terj,. M. Hashem, Masyarakat dan Sejarah, Bandung, Mizan, 1995, Cet. V

Rafi'un dan Djaliel, Maman Abdul, Prinsip dan Strategi Dakwah, Bandung, Mizan, 1999.

Rahmat, Jalaluddin, Psikologi Komunikasi, Bandung, Remaja Rosdakarya, 1996.

Sudaryana, Arif, Motivasi Variabel Prediktor Arah Perilaku Konsumen, Jakarta, Jurnal Kajian Bisnis, 2009.

Syukir, Asmuni, Dasar-Dasar Strategi Dakwah Islam, Surabaya, Al Ikhlas, 1983 